\title{
ELECTORAL LAWS AND THE 2007 GENERAL ELECTIONS IN NIGERIA
}

\author{
E Remi Aiyede
}

E Remi Aiyede is a lecturer in and Director of Postgraduate Affairs, Department of Political Science University of Ibadan, Nigeria

Ibadan, Oyo State, Nigeria 100005

Tel: +234 8050321282

e-mail: eaiyede@yahoo.com

\begin{abstract}
Credible elections are a salient indicator of democratic consolidation and the principal institutionalised means of forming and changing democratic governments. A central determinant of the success of any election is the institutions which structure the behaviour of participants and the choices available to them, hence their belief in pay-offs to individuals and groups. The guiding principles and regulations of the 2007 general elections in Nigeria are to be found in the 1999 Constitution and in the Electoral Act 2006. These documents not only set out the rules, the enactment of the Electoral Act usually signals the beginning of the electoral contest. The Constitution and the Act together make elaborate provision for voter registration, party and candidate registration, campaign financing and regulation, election observation, ballot design, polling stations, voting, counting, and tabulation, election management bodies, and disputesettlement authorities. This paper reviews critically the constitutional provisions on elections and the Electoral Act 2006 in the context of the challenges of achieving credible elections in Nigeria.
\end{abstract}

\section{INTRODUCTION}

Ever since 1959, when the first general elections took place, elections in Nigeria have been mired in controversy and characterised by court cases over electoral outcomes. Not only have such cases revealed widespread electoral malpractice and fraud which threaten democratic consolidation, the laws governing elections have been identified as critical to the dismal electoral practices. Albert (2007, p 1) 
pointed out the 'past failure of the legal system to protect individual and political rights to prosecute those behind the many cases of electoral violence and fraud, and curb the excesses of political incumbents in the country'. It is therefore no wonder that the 1999 Constitution envisaged a need for constant review of the rules of the electoral process to deal with emerging problems by empowering the National Assembly to make laws to guide the general conduct of elections, in addition to making general provisions that govern electoral competition, electoral structures and political parties.

It also established and empowered the Independent National Electoral Commission (INEC) to manage elections within the general framework of the law. The emerging tradition since 1999 is that the National Assembly produces or revises an existing Electoral Act just before the commencement of a general election. Thus, the revision of an existing Electoral Act or the production of a new one usually signals the start of the 'high political season'. What is the character of electoral laws in Nigeria? What are the issues addressed by these laws? What are the consequences of these for the electoral system, the party system, electoral conflicts, campaign finance, and their general implications for democratic consolidation and political stability?

This paper reviews the basic laws that governed the 2007 general elections in Nigeria. It examines their coverage, consequences and effects on the electoral system, the party system, electoral competition and electoral dispute resolution. It explores their implications for democratic consolidation in the country. The paper argues that the electoral laws are very broad and cover a great deal of ground when viewed against the backdrop of the laws that governed the 1999 and 2003 elections. There are elaborate provisions about electoral malpractice and violence as well as opportunities for redress in cases of contrived exclusion of candidates.

It notes, however, that the provisions on political finance favour the ruling political parties and that the laws encourage the existence of small parties because they remove the incentive for such parties to merge into a strong opposition, thereby ameliorating Duverger's law that a single member plurality vote (SMP) leads to a two-party system. Furthermore, the electoral laws have succeeded in overcoming the tendency of parties to be ethnically based, because they require national representivity in the composition of party executive bodies. But the electoral laws give too many responsibilities to the national electoral management body, INEC - from voter and party registration to the scrutiny of the finances of the parties and candidates. This partly accounts for the woeful performance of the body, as demonstrated in the series of petitions in the aftermath of the elections in which INEC is implicated. Thus, the paper calls for a deconcentration of the functions of the electoral management body. To safeguard fairness in the electoral 
process the judicial system needs to be strengthened and the rule of law promoted by political incumbents.

\section{ELECTORAL LAWS, ELECTORAL SYSTEM, PARTY SYSTEM AND DEMOCRATISATION}

Electoral laws form the foundation of an electoral system. Thus their character affects the possibility and speed of evolving a stable electoral system within given contexts. Electoral systems evolve out of electoral rules that have become embedded in a political culture as political actors acquire substantial skills in manipulating the rules in their self interest (Taagepera 2002, p 249). Whether those rules are simple or complex, the way in which they are chosen and the way they are put into use are important for the success of the electoral system. Thus, the effects of electoral laws must not be underestimated. Since Duverger published his Political Parties in 1954 it has generally been accepted that electoral laws have a mechanical and psychological effect on partisan competition and coalition formation. The dominant view is that the SMP system favours a two-party system.

Mozaffar argues that the choice of electoral rules is one of the most important decisions made in the democratisation process (2002, p 87). He considers two sets of rules to be important in this regard. The first endogenously structures electoral competition by encouraging strategic coordination among voters, parties, and candidates over votes and seats. It defines electoral formulas, district magnitudes, constituency boundaries and assembly size. In Nigeria, these rules are largely contained in the Constitution.

The second set of rules defines the broad institutional framework of electoral governance and the structures and procedures that regulate voter, party and candidate registration, election observation, campaign finance and media access, voting, counting, tabulation and reporting of results, and the adjudication of electoral disputes. In Nigeria the broad institutional framework of electoral management, campaign finance and dispute adjudication is defined by the Constitution, while the Electoral Act provides more detailed and specific guidelines for registration, voting, vote count, tabulation and reporting of results, electoral offences, penalties and guidelines for dealing with electoral petitions and disputes.

In the literature debates about the first set of rules have often centred on the choice between the single-member plurality (SMP) system, also known as firstpast-the-post (FPTP), and the closed list proportional representation (PR) system, although there are intermediate systems. SMP electoral rules involve one-person legislative districts in which the person who receives the most votes is declared elected, while the PR is a system in which voters vote for a party list rather than an individual candidate in a multi-member district. 
According to Duverger SMP restricts the number of political parties that are potential contenders for office and creates a tendency towards a two-party system. Indeed, it facilitates the emergence of single-party majority governments by turning pluralities of votes into a majority of legislative seats. SMP also leads to some votes being 'worth more' than others in vote-to-seat conversions. Relatively small parties whose support is diffused across the whole political system without a territorial stronghold are likely to be severely punished in vote-seat conversions, while parties of similar size with geographically concentrated support may get a bonus.

The system also tends to lead to centrist, non-ideological pragmatic or 'brokerage' politics as parties compete for the 'median voter'. It increases incentives for strategic voting, since a vote for a minor-party candidate may be wasted, leading to the voter's least-preferred candidate being elected. It tends to reinforce perceptions of regional exclusion and grievances because it expands the advantage enjoyed by the largest political party in a region in vote-seat conversions and punishes relatively smaller parties.

When used at the provincial level it may allow the majority social group in a territory to govern alone, while facilitating the consistent exclusion of ethnic, linguistic or religious minorities from political power.

It may allow a political party that is hostile to national unity to gain a strong power base through control of a single-party majority government in a state, which it can then use to pursue separatist policies and popular sentiments. Given the above, the tendency around the world is for countries to move away from SMP to some sort of PR or modified SMP to reduce its negative effects.

$\mathrm{PR}$, on the other hand, tends to increase the number of parties that are likely to compete in elections, depending on the threshold and size of electoral districts. This is because no party is likely to be seen by voters as a wasted choice. It makes it unlikely that a single party will hold a majority of seats in the legislature, and thus makes either minority or coalition governments the norm in parliamentary systems. In such contexts, the composition of a government and the policies of that government are likely to be decided not by the election but as the result of post election negotiations among party leaders. The major problem is that this weakens the ability of legislators in parties that operate nationwide to act as regional representatives, since they are likely to be bound by party discipline. It leads to programmatic parties which seek distinctive appeals to relatively narrow shares of the electorates (Reynolds \& Reilly 1997, ch 3).

Under the third wave of democratisation attempts have been made to examine how these tendencies found in established democracies play out in new democracies, such as the post-communist states in Eastern Europe, Latin America, Africa and Asia, as they trudge towards consolidation. These attempt, as Moser 
(1999, p 1) has noted, not only assess the reach of Duverger's laws, they provide an avenue for interrogating the claims of the new institutionalism that institutions have a political effect that is, to some extent, independent of their social and political context. Thus, this paper is concerned with deepening our understanding of the challenge of electoral laws as instruments for managing elections in order to enrich reflection on the theoretical debate on the effects of electoral laws on politics and the possibilities of democratic consolidation, with emphasis on the experience in Nigeria.

The concern with the second set of rules essentially focuses on electoral fraud, electoral and administrative irregularities. The target here is to evolve electoral legislation to reduce fraud and irregularities and to design neutral and fraudfree election procedures. It covers the election management bodies, their functions or roles, as well as the roles of election tribunals. The most critical issue is the extent of the autonomy of election management bodies, their capacity to carry out assigned functions and the neutrality of electoral tribunals (see Lehoucq 2002). In Africa the controversies and disputes surrounding transition elections focused principally on such issues as pro-incumbent bias in rule application, inflated or incomplete voters' rolls, and restrictions on opposition access to state-controlled media (Mozafar 2002, p 88). This paper also attempts to characterise Nigeria's electoral system, as created by the various laws and the way they relate to Duverger's principles, as well as their challenges for democratic practice and consolidation.

\section{RULES GOVERNING THE STRUCTURE OF ELECTORAL COMPETITION IN NIGERIA}

\section{Assembly Size, District Magnitude and Electoral Formula}

The broad rules governing the structure of electoral competition are to be found in the 1999 Constitution. The provisions not only cover such issues as qualifications of candidates for election to the various posts, electoral formulas, district magnitudes, constituency boundaries and assembly size, they also reflect the federal character of the country by providing for each level of government.

Sections 48 and 49 of the Constitution provide, respectively, for three senators from each state and 360 members of the House of Representatives. While the distribution of membership of the Senate is based on an equal number per state, membership of the House of Representatives is based on the population of each state. Section 71 defines the magnitude of the districts and constituencies, while s 73 prescribes the basis and manner of the review of senatorial districts and federal constituencies. Such a review is to be done by INEC at intervals of not 
less than ten years. Section 74 subjects such a review to the approval of the National Assembly. Section 75 requires that the population be ascertained by reference to the latest national census figures.

Following the single member district formula, s 77 stipulates that each senatorial district or federal constituency 'shall return one member who shall be directly elected to the Senate or the House of Representatives'. The federation is regarded as one constituency for the purpose of electing the president. If a single candidate is nominated as president there is a 'Yes' or 'No' vote. To become president, such a candidate must not only win the majority of 'Yes' votes, he or she must record 'not less than one-quarter of the votes cast at the election in each of at least two-thirds of all states in the federation and the FCT'. According to s 134, where there are two or more candidates the winner must have a majority of votes cast in addition to 'not less than one-quarter of the votes cast at the election in each of at least two-thirds of all states in the federation and the FCT'. Where no clear winner emerges there must be a run-off election between the two highest performing candidates.

Sections 32 to 42 of the Electoral Act 2006 deal with the nomination of candidates. Political parties submit a list of candidates to INEC not later than 120 days before the general election. The Act prohibits the nomination of more than one candidate for election to a particular office. A party may, however, change any of its candidates 60 days before the elections (s 34). In case of the death of a candidate the Chief National Electoral Officer or the Resident Electoral Commissioner must countermand the poll in which the candidate was to participate and set another date for the election (s 37). Section 65 (1 and 2) of the 1999 Constitution stipulates the conditions of eligibility for the Senate and the House of Representatives. It states that a candidate for the Senate should be a Nigerian citizen, at least 35 years old, hold a school certificate, be a member of a party and be sponsored by that party. The minimum age for membership of the House is 30 years.

\section{RULES DEFINING THE BROAD INSTITUTIONAL FRAMEWORK OF ELECTORAL GOVERNANCE}

\section{Election Management Body}

One of the most significant aspects of the electoral laws relates to the electoral umpire, INEC. Section 153 of the 1999 Constitution establishes the Independent National Electoral Commission while Section F Part I of the Third Schedule of the Constitution defines its composition and powers. The section states that the commission must be made up of a chairman and 12 other members (electoral commissioners) appointed by the president in consultation with the National 
Council of States and subject to confirmation by the Senate. A resident electoral commissioner must be appointed by the president for each state of the federation.

INEC is charged with organising, undertaking and supervising all elections to the offices of president and vice-president, governors and deputy governors of states, and members of the Senate, the House of Representatives and the House of Assembly of each state of the federation. It must register political parties in accordance with the provisions of the Constitution and an Act of the National Assembly; monitor the organisation and operation of the political parties, including their finances; and arrange for the annual examination and auditing of the funds and accounts of political parties and publish a report for public information. In addition, the commission must arrange and conduct voter registration and prepare, maintain and revise the register of voters for the purpose of any election under the Constitution. INEC monitors political campaigns and establishes the rules governing political parties and ensures that all electoral commissioners, electoral and returning officers take and subscribe to the oath of office prescribed by law. It may delegate any of its powers to any resident electoral commissioner and must carry out such other functions as may be conferred upon it by an Act of the National Assembly.

The Electoral Act 2006, drawing on s 226 and 227 of the 1999 Constitution, expands the functions of INEC to include (a) conduct of 'voter and civic education', (b) promotion of 'knowledge of sound democratic election processes', and (c) conduct of 'any referendum required to be conducted pursuant to the provision of the 1999 Constitution or any other law/Act of the national Assembly' (s 2). Sections 157 and 158 attempt to guarantee INEC's independence by stipulating that the president may only remove members of the commission if requested to do so by a two-thirds majority of the Senate. In 'exercising its powers to make appointments or to exercise disciplinary control over persons' the commission is not subject to the direction of any person or authority. The Electoral Act 2006 further gives INEC the power to appoint its own secretary, who is the head of administration. It also makes it impossible for the president to single-handedly remove a resident electoral commissioner in any state. The Act prescribes that a resident electoral commissioner can only be removed by the president if requested to do so by a two-thirds majority of the Senate on the grounds of inability to discharge the functions of his or her office or for misconduct. In the past the president has been able to remove or redeploy these officers at will.

\section{Party Formation}

The Constitution envisages political parties that are national in character. It requires party membership to be open to every citizen of Nigeria irrespective of 
his or her place of origin, circumstance of birth, sex, religion or ethnic origin. Parties must be registered with INEC. The name of the association, its symbol or 'logo' must not contain any ethnic or religious connotation or give the impression that its activities are confined only to one part of the geographical area of Nigeria. The headquarters must be situated in the Federal Capital Territory (FCT). Members of the executive committee of the party must also reflect the federal character of Nigeria, while its principal officers and members of its executive committee must be elected periodically on a democratic basis.

Part IV of the Electoral Act 2006 deals with the party system. It restates the conditions specified by the Constitution for the formation of political parties, with specific additions. These include: the penalties for contravention of s 227 of the Constitution, which prohibits the formation of quasi-military organisations. According to s 81 of the Act, such a contravention carries a fine of $\$ 500000$ for the first instance, $\$ 700000$ for any subsequent offence and $\$ 50000$ for every day the offence is committed. The party also forfeits the grant due to it 'for the year the offence was committed, and for every year in which the offence continues'. Any group or persons that 'aids or abets a political party in contravening that section of the constitution shall face a fine of $\$ 500000$ or three years' imprisonment or both'.

Sections 82 and 83 deal with party symbols, while s 84 deals with mergers of political parties. Section 85 contains regulations for party conventions, congresses, conference and meetings. It empowers INEC to attend or monitor such meetings without prior notice to the party, while mandating parties to give at least 21 days' notice of any convention, congress, conference or meeting convened to elect 'members of its executive committees, other governing bodies or nominating candidates for any elective posts...'

A political party must provide any required information or clarification sought by INEC on pain of a fine of not less that \$500 000 .

\section{ELECTION TIMETABLE, REGISTRATION AND VOTING PROCEDURE}

Section 31 of the Electoral Act requires INEC to produce a timetable not less than 150 days before the day set for the election. The timetable must be published in a notice in each state of the federation and the FCT. It must include the date of the election and the place where nomination papers are to be delivered. The notice must also be published in each constituency in respect of which an election is to be held.

Section 76 of the Constitution defines the specific time of elections for the National Assembly. While INEC must set the election date such a date 'shall not be earlier than sixty days before and not later than the date on which the House 
stands dissolved'. Section 77 stipulates direct election in a single member district and establishes 18 years as the voting age. Section 78 empowers INEC to register voters and conduct elections, while s 79 empowers the National Assembly to make provisions in respect of electoral disputes. Similar provisions are made in ss 112 to 119 of the Constitution for state-level elections.

Sections 132 and 133 contain special provisions for presidential and gubernatorial elections. According to 132 INEC must set the date for election to these offices 'not earlier that sixty days but less than 30 days before the expiry of the term of office of the last holder of the office'. This section also permits INEC to extend the date for nomination if by the time nominations close only one candidate has been nominated. Section 221 prohibits all associations except political parties from canvassing votes or contributing to the election expenses of any candidate. There are similar provisions in respect of gubernatorial elections in $\mathrm{s} 179$.

Part III of the Electoral Act 2006 makes elaborate provision for voter registration, which must end not more than 120 days before any election (the Electoral Act 2002 set the period at 60 days). The Act prohibits surrogate registration. Although it provides that a duplicate copy of a registration card may be issued on application within 30 days before an election this can only be done by an electoral officer or other authorised persons once they are satisfied about the circumstances of loss, destruction or defacement of the original card. Any person who issues a duplicate voter's card on polling day or within 30 days of polling day is liable on conviction to a fine not exceeding $\$ 200000$, or to imprisonment not exceeding two years, or both. This section goes on to list a series of offences associated with voter registration with penalties attached. Such offences include unlawful possession of a voter's card and the buying and selling of a voter's card.

Copies of the voters' register are to be displayed for public scrutiny for a period of 5 to 14 days in each local government and area council or ward. This is to enable registered voters to crosscheck in case of omissions or errors. A supplementary voters' register may be created for the purpose of such corrections and integrated into the voters register not later than 60 days before a general election.

Part IV of the Electoral Act of 2006 empowers INEC to determine the procedures during an election. Election results are to be announced by the electoral officer, who is to act as the returning officer for election to the office of chairman of area council in the FCT. The results are to be announced by: the presiding officer at the polling station or the ward returning officer at the ward collation centre or the returning officer at the local government or area council or the returning officer at the state constituency collation centre or the returning officer 
at the federal constituency collation centre or the returning officer at the senatorial district collation centre or the resident electoral commissioner, who shall be the returning officer for the governorship election; or the chief electoral commissioner, who shall be the returning officer for the presidential election (s 28).

\section{CAMPAIGN FINANCE}

Section 221 of the Constitution provides that: 'No association, other than a political party, shall canvass for votes for any candidate at any election or contribute to the funds of any political party or to the election expenses of any candidate at an election.'

Sections 225, 226 and 227 deal with the financing and accountability of parties. They require political parties to submit to INEC detailed annual statements and analyses of sources of funds and other assets and statements of expenditure. INEC is expected to submit to the National Assembly a report on the accounts and balance sheet of every party. Section 88 of the Electoral Act complements this provision by specifying the period to be covered as 1 January to 31 December each year. The Act also empowers INEC to authorise any of its officers to access the records and audited accounts kept by a party. The commission is to publish such examination or audit in three national newspapers.

Section 229 of the Constitution interprets 'association' as any body of persons, corporate or unincorporated, which agree to act together for any common purpose, and includes an association formed for any ethnic, social, cultural, occupational or religious purpose. Section 228 enables the National Assembly to make laws providing for the punishment of any person involved in the management or control of any political party, found after due inquiry to have contravened ss 221, 225 (3) and 227 of the Constitution.

The Electoral Act 2006 regulates campaign finances, expanding on the provisions of the Constitution. Section 87 of the Electoral Act sets out penalties for offences relating to the finances of political parties. Any party that contravenes s 225 (3) of the Constitution, which deals with money transferred from abroad, commits an offence and is liable on conviction to a fine of not less than \$500 000 and the forfeiture of the funds or assets to INEC. Section 79 makes it mandatory for parties to provide INEC with a statement of election expenses.

Related to these provisions is the Companies and Allied Matters Act (CAMA), 1990. Section 38 (2) of this Act precludes a company from making a donation or gift of any of its property or funds to a political party or association for political purposes. The law provides that officers in default shall be liable to refund to the company the sum or gift. The company or its officers shall also be guilty of an offence and liable to a fine. 
Section 90, however, empowers the National Assembly to approve a grant to political parties contesting elections. Section 91 2(a) states that 10 per cent of the grant (30\% in Electoral Act 2002) is to be shared equally among all registered political parties. Section 2(b) states that the remaining 90 per cent must be shared among the registered political parties in proportion to the number of seats won by each party in the national Parliament.

Sections 92, 93 and 94 deal with campaign contributions. Each party must keep a record of all contributors and the amount contributed. Section 93 puts a ceiling on expenditure incurred by candidates according to the office for which they are standing. This is presented in the table below.

Table 1

Ceiling on Campaign Expenditure

\begin{tabular}{|l|c|}
\hline Candidates & \begin{tabular}{c} 
Maximum Election Expenses \\
\hline Presidential candidates
\end{tabular} \\
\hline Gubernatorial candidates & 10000000000 \\
\hline Senatorial candidates & 20000000 \\
\hline Candidates for the House of Representatives & 10000000 \\
\hline Candidates for State House of Assembly & 5000000 \\
\hline Candidates for Chairman of Local Government & 5000000 \\
\hline Councillorship candidates & 500000 \\
\hline
\end{tabular}

Section 93(11) states that any contravention of the above provisions is subject to a maximum fine of $\$ 500000$, or nine months' imprisonment, or both, while any accountant who ' falsifies or conspires or aids a candidate to forge or falsify a document relating to his expenditure at an election or receipt or donation for the election commits an offence that is liable to 10 years imprisonment'.

Section 95 also provides for adequate disclosure of the sources of campaign contribution. Parties must keep records showing the name and address of any person or entity that contributes money or other item in excess of \$1 000000. 


\section{Electoral Offences}

Part VIII ss 124-139 of the Electoral Act sets out a detailed list of electoral offences from improper use of voters' cards to disorderly behaviour at political meetings, wilful defacement or destruction of nomination papers, forgery of a registration card, or knowingly giving false information or making false statements in regard to any application for registration. The penalties for these offences are also clearly stated. Section 139 of the Act asserts that these offences apply to the recall of a member of the legislature and local government councillors. ${ }^{1}$

\section{Security}

Section 96 of the Electoral Act provides for security at political rallies and processions. The police commissioner in each state must ensure security. Section 96(2) bars people from carrying 'offensive weapons or missiles', setting down a fine of $\$ 100000$, or imprisonment for a term of two years, or both, for contravention of the section. Section 97 prohibits the use of foul language which may provoke violent reactions and emotions during political campaigns. Places of religious worship, police stations, and public offices may not be used for political rallies. Masquerades are not allowed during political campaigns or for any political purposes.

Section 98 bars the use or threat of the use of force or violence during political campaigns. The contravention of this provision attracts a fine of $\$ 50000$ or six months' imprisonment. In the case of a political party the fine is $\$ 250000$ in the first instance and $\$ 500000$ for any subsequent offence.

\section{Election Petitions and Electoral Tribunals}

Part IX s 285 of the Constitution is devoted to election petitions and provides for the establishment of electoral tribunals. Specifically, it gives the president of the Court of Appeal, in consultation with the chief justices of the states, the presidents of the Customary Court of Appeal of the states and the Khadis of the Sharia Court of Appeal the power to establish one or more election tribunals to determine the validity of an election, the term of office of any person, when a seat has become vacant and when a petition presented to court in respect of an election is properly made.

1 Recall is a political process whereby a member of Parliament is removed from office by his or her constituency if members of that constituency believe he or she does not represent their interests. 
One or more National Assembly electoral tribunal must be established to hear petitions concerning the outcome of elections, the term of office of an individual, and whether the proper procedure has been observed in relation to a petition. Governorship and legislative house election tribunals are established at state level for the same purpose.

Appeals against decisions made by election tribunals go to the Court of Appeal, whose decision is final. However, petitions arising from presidential elections go directly to the Court of Appeal and it is the Supreme Court that is the final arbiter in respect of appeals against decisions made by the Appeal Court in these cases. The Electoral Act 2006 provides for the establishment of an election tribunal for the local council elections in the FCT. Election tribunals must be constituted not later than 14 days before election and an election petition must be lodged within 30 days after the results are declared (s 141).

Section 144 sets out those with locus standi to present an election petition. They are a candidate in an election or a political party which participated in the election.

According to s145 an election may only be questioned on the following grounds:

- that a person whose election is questioned was, at the time of the election, not qualified to contest the election;

- that the election was invalid by reason of corrupt practices or noncompliance with the provisions of the Act;

- that the respondent was not duly elected by a majority of lawful votes cast at the election; or

- that the petitioner or its candidate was validly nominated but unlawfully excluded from the election.

Section 147(1) empowers the tribunal to nullify an election if it determines that an elected candidate was not validly elected. Subsection 2 empowers the tribunal or court to declare as elected another candidate who is determined to have scored the highest number of valid votes cast where the candidate who was returned as elected did not win a majority of valid votes. Section 149 gives 21 days from the date of the decision of an election tribunal or court for an appeal against the decision. The rules of procedures for election petitions and appeals are set out in the first schedule of the Electoral Act.

\section{On Media Access}

The Act (s 102) sets out ways of checking bias in the application of rules or restrictions placed on opposition access to state-controlled media. Subsection 2 
makes the denial of access and equal time 'an offence punishable, in the first instance, with a maximum fine of $\$ 500000$ and the withdrawal by the National Broadcasting Commission of the licence of the offending electronic media house for a period of 12 months on any subsequent violation'.

\section{EVALUATION OF CONSEQUENCES, ISSUES AND CHALLENGES}

The process of enacting the Electoral Act usually signals the start of the electioneering process in Nigeria. Public debates over the content of the Act usually take centre stage in public discourse as parties and candidates mobilise to ensure that their interests are catered for. The first Electoral Act after the return to democratic rule in 1999 was the 2001 Act, certain clauses of which were mired in controversy because they were perceived to have been smuggled into the document after the Bill had been passed by both chambers of the National Assembly. One of the contentious clauses (s 80(1)(c)) required new political associations seeking registration to secure at least 15 per cent of local council seats in two-thirds of the 36 states of the federation and the FCT before they could be registered as political parties.

This action was challenged in many newspaper editorials and by the general public and was interpreted as an attempt by the ruling Peoples Democratic Party to muzzle opposition and to prevent a schism within the party. The party has had severe internal conflicts over political appointments and resource distribution, with breakaway threats made by some powerful and influential members who allege that they are marginalised in relation to decision-making.

The 2001 Act also banned governors from standing for a third term of office. It was aimed at governors belonging to the opposition All Nigerian Peoples Party (ANPP) and the Alliance for Democracy (AD).

This effort to shrink the political space through legal provisions failed when Gani Fawehinmi, human rights lawyer and presidential candidate of the National Conscience Party (NCP), joined other aspirant political parties in seeking a judicial interpretation of s 222 of the 1999 Constitution relating to the registration of political parties (see Ologbenla 2003). The 2001 Electoral Act was repealed before it came into operation and replaced with the 2002 Electoral Act.

Although there was no similar controversy over the Electoral Act of 2006 it was preceded by an attempt to amend the Constitution to extend the tenure of the president and state governors, an attempt which generated strong divisions among the political elite. Indeed, it marked a high point in the conflict between President Obasanjo and vice-president Alhaji Atiku Abubakar, leading to the removal of the vice-president after he abandoned the PDP for the Action Congress (AC). It took a ruling of the Supreme Court to restore Atiku to the office of vice-president. 
Once the constitutional amendment proposal was defeated in Parliament the president publicly declared the 2007 election a 'do-or-die affair' for the PDP, which was afflicted with political schisms. Thus, the atmosphere during the 2007 election was unusually tense.

Certainly the various provisions of the electoral laws have had consequences for the electoral system in Nigeria and the constitutional provisions have created a modified SMP vote system. This system is fairly simple to operate and has led to clear-cut wins by the PDP, which prides itself on being the largest party in Africa. But this simplicity has been overestimated and important logistical implications are frequently not addressed, leading to severe setbacks in the management of elections. These logistical difficulties provide opportunities for the more resource-endowed parties to manipulate the process to their own advantage.

Duverger's law that SMP will lead to a two-party system has not yet been proved in Nigeria, but it is clear from the performance of parties during the last elections that voters may eventually tend to rally to the two most acceptable parties.

Currently, the party system is unstable, with floor crossing and schisms leading to a proliferation of parties. Three parties contested the 1999 elections, 27 the 2003 elections and 50 the 2007 elections. Most of these parties are 'broad churches', encompassing all shades of opinion and ethnicity as a result of the constitutional requirement that parties reflect the federal character of the country in the composition of their executive bodies and membership, thereby preventing the emergence of extremist parties that are geographically concentrated.

Only 25 of the 50 political parties that contested the 2007 elections put up presidential candidates. Table 2 shows the relative strengths of the parties. Obviously, the PDP remains dominant, although many of the results are still in dispute.

INEC is the most visible and critical organ of governance for elections. It is not only central to the making and application of rules it also plays an active role in the process of adjudication. It usually plays a major role in drafting the electoral Bill, which the executive presents to the National Assembly. Since 1999 two such pices of legislation - the Electoral Act 2002 and the Electoral Act 2006 - have been crafted by INEC, presented to the National Assembly, and enacted.

In general, the functions of INEC are too broad. This is particularly obvious in relation to the monitoring of party finances. It is clearly impractical to expect INEC to acquire the investigative capacity to determine or track down political parties that cleverly flout the transparency requirements of the Electoral Act 2006, particularly s 95, which states that no party 'shall accept or keep in its possession any anonymous monetary or other contributions, gifts, properties, etc from any source whatsoever'. There is a similar problem with monitoring the ceiling placed 


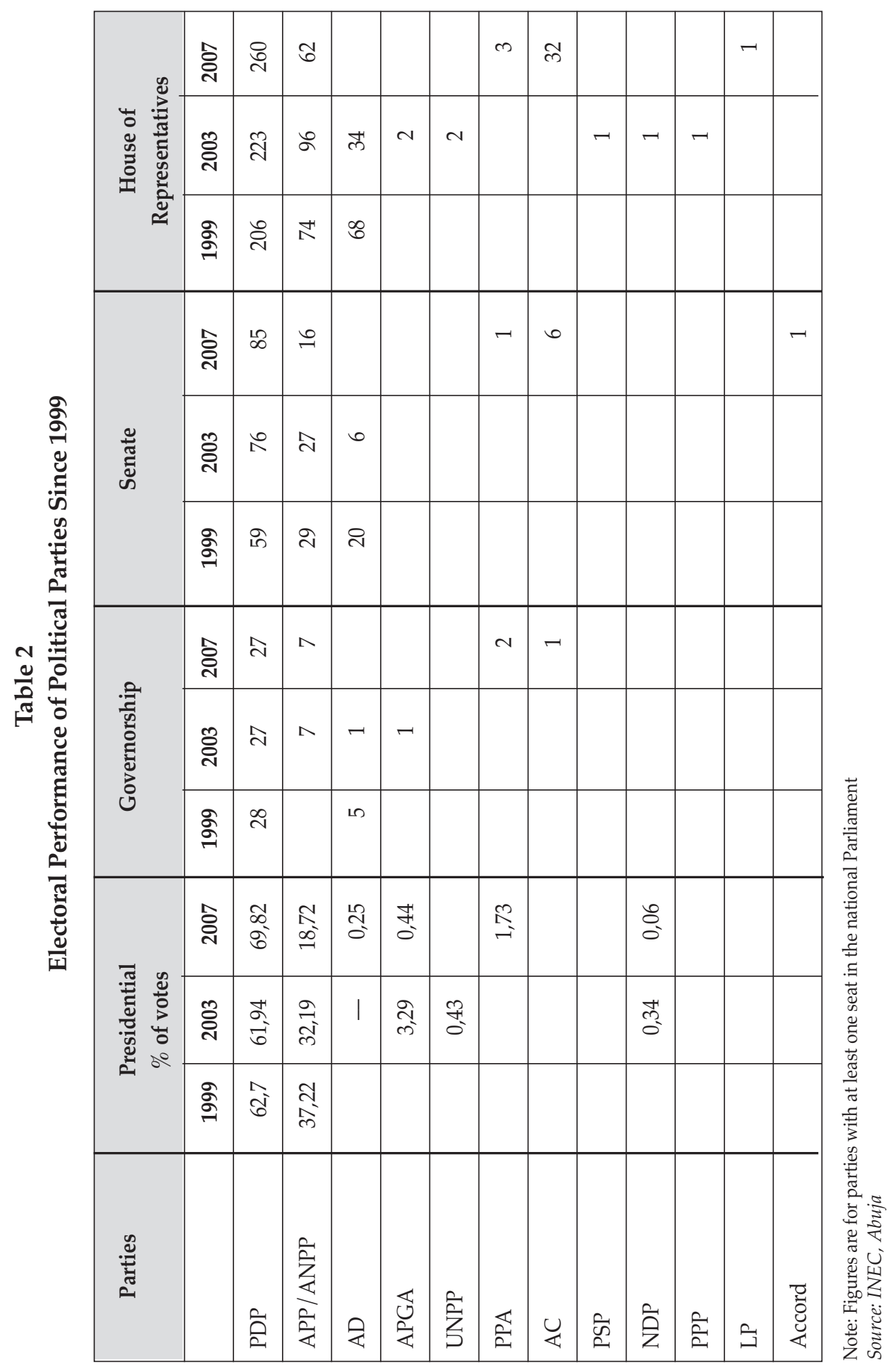


on election expenses (s 93 of the Act) and the clause that prevents political parties from holding or possessing funds outside Nigeria. INEC itself has admitted that it cannot effectively audit political party accounts (INEC 2005, p 19) and it does not appear to be able to cooperate with other law enforcement agencies to enforce the provisions.

Questions about the integrity and independence of INEC have emerged in the light of controversies and lawsuits that have followed successive elections and of court decisions on election matters since 1999. Indeed, there are several established claims of complicity of its officials in electoral malpractice and the courts have overturned its official decisions. INEC's bias could be linked to the fact that its chairman is appointed by the president, whose party also dominates Parliament.

The Electoral Act 2006 has taken into account factors that give incumbents an advantage with regard to their influence over INEC but it has not gone far enough in controlling those. The Guardian (19 April 2007, p14), in an editorial, observed that 'the Commission demonstrated its partisanship by taking actions, including flouting court orders, and initiating court cases of its own, all of which conspired to advance the electoral fortunes of the ruling Peoples Democratic Party'. The long-term goal should be to ensure that the members of INEC are drawn from all registered political parties and cannot be removed except by a resolution of two-thirds of the members of the National Assembly. This would require a constitutional amendment, since the structure of INEC and mode of appointment of its officers are constitutional issues.

There are also problems of capacity and competence, which aggravate INEC's bias and make it ineffective in performing many of its ascribed functions. It is particularly weak in monitoring and reporting and, as a result, no charges have been brought against parties or candidates who might have breached the laws on campaign finances. Indeed, there is no record that anyone has been prosecuted for electoral crimes. In October 2007, five months after the general elections, the Chairman of INEC, Professor Maurice Iwu, claimed that the police had compiled a list of electoral offenders but that if they were prosecuted it would affect ongoing cases before the tribunal 'because the criminal cases would supersede the electoral cases' (Fabiyi 2007, p 11).

Some provisions of the Electoral Act do not take into account the logistical challenges for INEC. The Guardian, in the editorial cited above, bemoaned the shoddy 'preparations made by INEC' and its failure 'to release voters register to give Nigerians the chance to verify their names'. Section 64 (4) of the Electoral Act 2006 requires the presiding officer to count and announce the results at the polling station, but it fails to deal with the security implications of this action. Polling unit results are often not announced at the polling station. There is also 
no evidence that defaulting officers are punished. The commission has apparently been unable to display the voters' register as required by ss 14 and 20 of the Act.

A significant number of election petitions have been lodged challenging results announced by INEC.

Table 3

Tribunal Cases Arising from the 2007 National Elections

\begin{tabular}{|l|c|}
\hline Category & Number of cases \\
\hline Presidential & 8 \\
\hline Governorship & 105 \\
\hline Senate & 150 \\
\hline House of Representatives & 331 \\
\hline State House of Assembly & 656 \\
\hline Total & 1250 \\
\hline
\end{tabular}

Source: Adapted from Fabiyi (2007, p 11)

Several parliamentary elections at both state and federal level have been annulled by the tribunals, many of them because INEC failed to comply with various laws. In Oyo State INEC, in its submission to the tribunal, admitted to an 'error of omission'. In the FCT, Senator Jubrin Wowo's election was annulled because INEC unlawfully excluded the Progressive Action Congress (PAC) candidate from participating in the election. In her judgement Justice Josephine Tukur rebuked INEC for failing to abide by the provisions of the Electoral Act in the conduct of the elections. She pointed out that although INEC had excluded the candidate it had allocated votes to him in the declared results.

Seventeen political parties were screened by INEC for the polls, but the election results credited votes to 20 candidates. This is unlawful and unacceptable. We agreed with the submission of the petitioner that votes were just allotted to candidates by INEC. The omission of Ndako's party's name and logo in the ballot papers made it impossible for anyone to vote for him in the election. 
Thus far six gubernatorial election petition cases - in Ogun, Kogi, Adamawa, Kebbi, Anambra, and Rivers - have been decided by various courts and tribunals. The decisions and their status are summarised in Table 4. As noted above decisions of the election tribunals are subject to appeal.

Table 4

Court Decisions on Gubernatorial Election Petitions

\begin{tabular}{|c|c|c|}
\hline State & Court & Decision \\
\hline Anambra State & The Supreme Court & $\begin{array}{l}\text { Election nullified on the } \\
\text { grounds that the tenure of the } \\
\text { incumbent governor had not } \\
\text { yet ended and the election } \\
\text { was a violation of the } \\
\text { Constitution. }\end{array}$ \\
\hline Kogi State & Election Petition Tribunal & $\begin{array}{l}\text { Election nullified on the } \\
\text { grounds of unlawful } \\
\text { exclusion of opponents. }\end{array}$ \\
\hline Kebbi State & Election Petition Tribunal & $\begin{array}{l}\text { Election nullified because the } \\
\text { governor was not duly } \\
\text { nominated by the PDP, having } \\
\text { initially stood for the } \\
\text { ANPP before making an } \\
\text { unlawful switch to the PDP } \\
\text { when he was not even } \\
\text { officially registered as a } \\
\text { member. }\end{array}$ \\
\hline Rivers State & The Supreme Court & $\begin{array}{l}\text { Governor Omeha was deposed on } \\
\text { the grounds that he had not won } \\
\text { the party primaries and thus was } \\
\text { never a lawful candidate for the } \\
\text { PDP. Rotimi Amaechi, who was } \\
\text { initially nominated as the } \\
\text { gubernatorial candidate for the } \\
\text { PDP but was replaced by the party } \\
\text { leadership, was installed as } \\
\text { governor. }\end{array}$ \\
\hline Adamawa State & Election Petition Tribunal & $\begin{array}{l}\text { Election nullified on the grounds } \\
\text { that Action Congress (AC) } \\
\text { candidate Alhaji Ibrahim Bapetel } \\
\text { was wrongfully excluded. }\end{array}$ \\
\hline Ogun State & Election Petition Tribunal & $\begin{array}{l}\text { Petition of opposition struck down } \\
\text { on technical grounds. }\end{array}$ \\
\hline
\end{tabular}

Source: Adapted from Nwachuku (2007, p 58) 
One of INEC's major problems is finance. Not only is the body unable to muster enough funds, the Federal Ministry of Finance sometimes withholds payments, thereby causing it to postpone or delay the performance of some of its critical electoral functions. There should be a guarantee of funds to INEC bodies outside of the executive budget.

The provisions of the Electoral Act in relation to those seeking redress in the courts and the process involved is demanding, cumbersome, and discouraging and the process is long drawn out. The most notorious case is that of Ngige vs Obi in Anambra State where a governor who had been in office for almost three years of a four-year term, was proved to have been wrongly declared winner (Ameh 2006, p1). While the courts have tried to expedite action on election matters, any future Act should take this into account (Okoye 2007).

The categories of those who may seek redress in relation to an election result are restricted and exclude voters, a restriction of locus standi which limits justice. A liberal interpretation of locus standi would favour the search for even-handed justice in Nigeria. The capacity to sue must be re-addressed. Every Nigerian voter has a stake in the success of democracy in the country and the law should not impede any stakeholder from challenging actions that seek to threaten that democracy.

One positive element of the Electoral Act 2006 is that a person who is validly nominated but wrongly excluded from an election can apply to nullify the poll. This means that INEC cannot be used to prevent a candidate from contesting an election - a power used in the past by incumbents to exclude a strong opponent. It also checks the excesses of 'godfathers' who undermine internal party democratic processes by handpicking candidates to be sponsored by the parties, regardless of the outcome of the party primaries.

\section{CONCLUSION}

Four critical issues stand out in relation to the electoral laws. The first has to do with the need to ensure an effective and independent election management body. The Electoral Act 2006 has attempted to deal with this issue but the effort has been very limited. A real adjustment in this regard calls for a constitutional amendment. This is difficult under the very rigid 1999 Constitution. Nonetheless, the provisions concerning election petitions have proven to be an effective safeguard against incumbent executive use of INEC to determine who participates in an election.

Judicial intervention has clearly established the fact that INEC does not have the power to disqualify any candidate who has been validly nominated from contesting an election except if the candidate has been indicted by a court of law. 
These provisions have also checked the tendency among political party kingpins to handpick candidates for election at the last minute, without due regard for party processes, as was the case in Amaechi vs PDP, in which the Supreme Court declared the former to be the legitimate candidate of the party in the 2007 gubernatorial election in Rivers and installed him as the governor of the state without calling for fresh elections.

Secondly, the laws, despite their elaborate provisions for electoral offences, have not been able stem the problem of rigging and violence. This is partly because the laws overload INEC with responsibilities which are quite beyond the scope of a single body. The logistics of conducting countrywide elections mean that INEC is overwhelmed during voting and counting. There is, therefore, a need to continuously strengthen INEC. Happily, the various judicial interventions have affected the timing of elections in some states and constituencies. Thus, gubernatorial elections will no longer be held simultaneously in all 36 states.

There is, nevertheless, a need to decentralise some of the functions of INEC. For instance, INEC $(2005$, p19) admits that it is unable to audit party accounts effectively. The anti-corruption bodies are better equipped to investigate and monitor campaign financing, while local governments or non-governmental organisations under the supervision and oversight of INEC could conduct the updating of the voters' register.

The provision on campaign financing favours the ruling party, since 90 per cent of the grant to political parties is distributed on the basis of the number of parliamentary seats they hold. However, the real challenge of campaign financing is the huge election expenditure which fosters corruption in government (The Punch, editorial, 9 June 2006). There is no evidence that INEC is able to ensure that parties observe the ceiling on campaign expenditure. Perhaps the anticorruption bodies should have a special programme in this regard. There is a need for effective policing and prosecution of defaulters.

Fourthly, a major consequence of the growing regard for the rule of law under the Yar' Adua administration is the increased effectiveness of the tribunals as a part of the electoral process. In the past INEC, by flagrantly disobeying court orders, has made it impossible for petitioners to access electoral documents. This has not been the case since Yar'Adua's government assumed office in May 2007. As far as electoral justice is concerned, success in achieving free and fair elections depends not only on the careful crafting of electoral laws but also on an effective, alert, active and independent judiciary. Developments in the election tribunals since the April 2007 elections have made it clear that electoral laws cannot be effective without the operation of the rule of law. 


\section{- REFERENCES}

Albert, I O. 2007. 'An Analysis of the Inauguration Speech of President Yar'Adua'. IDASA Conflict Tracking Dossier 7.

Ameh, J. 2006. 'Ngige Out, Obi in'. The Punch, Lagos, 16 March.

Balogun, O. 2007. 'More Dust as INEC Submits Report'. Daily Independent 18 October. Duverger, M. 1954. Political Parties. New York: Wiley.

Fabiyi, O. 2007. 'Poll: Tribunals Receive 1,250 Petitions - Iwu'. The Punch 17 October. Federal Republic of Nigeria. 1999. The Constitution of the Federal Republic of Nigeria. Lagos: Federal Government Printer.

— 2002. Electoral Act 2002. Lagos: Federal Government Printer.

— 2006. Electoral Act 2006. Lagos: Federal Government Printer.

INEC (Independent National Electoral Commission). 2005. Political Party Finance Handbook. Abuja: INEC, March.

Lehoucq, F. 2002. 'Can Parties Police Themselves? Electoral Governance and Democratisation'. International Political Science Review 23(1).

Moser, R G. 1999. 'Electoral Systems and the Number of Political Parties in Postcommunist States'. World Politics 51(3).

Mozaffar, S. 2002. 'Patterns of Electoral Governance in Africa's Emerging Democracies'. International Political Science Review 23(1).

Nwachuku, C. 2007. 'Five Governors and Still Counting?' ThisDay 20 November.

Okoye, F. 2007. 'An Overview of Disputes Arising from the Failed Electoral Process'. IDASA Conflict Tracking Dossier 7.

Ologbenla, D. 2003. 'Political Instability, Conflicts and the 2003 General Elections'.

In R Anifowose \& T Babawale (eds). General Elections and Democratic Consolidation in Nigeria. Lagos: Friedrich Ebert Foundation.

Reynolds, A \& B Reilly. 1997. International IDEA Handbook on Electoral System Design. Stockholm: International IDEA.

Taagepera, R. 2002. 'Designing Electoral Rules and Waiting for an Electoral System to Evolve'. In A Reynolds (ed). The Architecture of Democracy: Constitutional Design, Conflict Management and Democracy. Oxford \& New York: Oxford University Press. 